\title{
The Relationship between Willingness to Communicate in English inside the Classroom and Achievement in the Omani ELT Context
}

\author{
Nasser Al-Hinddasi: Shinass College of Technology, Oman.
}

\begin{abstract}
Willing to Communicate in English (WTC) when choice is given to the learners has been explored in different ELT contexts. The current quantitative study aims at investigating the WTC in the Omani tertiary level in relation to the students' achievement in a public speaking course. Data were gathered by administrating a modified version of Wietelak and Pawlak (2016) WTC inside the class questionnaire. The questionnaire was answered by 50 post foundation students compromising 14 males, and 36 females who registered in the public speaking course in the second academic semester 2018 in Shinas College of Technology, Oman. Additionally, their marks in the progress test in the speaking course were obtained. The results of the correlational analyses revealed that there was no significant relation between students WTC and their achievement in the Public speaking course. Also the results indicated that students avoid communicating in English frequently because of their limited linguistic abilities more than the other cultural and psychological reasons.
\end{abstract}

Key words: Willingness to communicate, English, Oman, Achievement.

\section{Introduction}

Willingness to Communicate (WTC) refers to the students "intention to initiate a discussion" when opportunities are provided (MacIntyre, Baker, Clément, \& Conrod, 2001). It was investigated in different EFL contexts as a helping factor to enhance L1 and L2 learning in school and college levels. For example similar studies were conducted in China (Peng \& Woodrow, 2010), in Japan (Yashima, 2002) and in Oman (Al-Amrani, 2011). The Willingness to Communicate was explored in relation to several factors in the classroom that include, social support (MacIntyre et al., 2001) motivation, communication anxiety (McCroskey, 1992), gender and age.

It might be noticed that WTC is somehow a context bound concept, which means that exploring it in a unique ELT context might provide different contributions to the field of teaching and learning particularly in the tertiary level. It seems that as students grow up, the fear of making mistakes and lose face when communicating in L2 develops and make them unwilling to speak. Hence, exploring the WTC in the Omani ELT context from the Omani students' perspectives, as a different cultural identity might provide new insights to the field of ELT and this will be discussed in the next section.

\subsection{Rational of the Study}

The ELT field in Oman has received a growing attention of research recently, particularly since 1998 when the basic education system was introduced to the country (Borg, 2006). Additionally, considerable amount of research was conducted in order to address many classroom issues in schools and higher education institutes. 
Furthermore, some research has explored the problems that face the Omani students in English, in college level and its impact on students' efficiency in the work place, where expatriates dominated the work environment and they tend to use English for communication. For example, the research in the Omani ELT context has revealed a lack in the communicative abilities in English language for fresh college graduates in Oman (Al-Mahrooqi, 2012). As a result, those students are likely to face difficulties in performing personal and social tasks. Moreover they might face difficulties to perform work requirements which demand English linguistic abilities which was similarly reported in the surrounding gulf countries by Moody (2009). Therefore, more attention should be given to exploring the current learning practices to identify the potential obstacles that face learners in the Omani ELT context.

Furthermore, some researchers argued that the English curriculums in Oman "need systematic evaluation to support practices in the field" (Al-Jardani, 2012). In addition to that, these curriculums are reported to be insufficient in "equip[ing] the students with the communicative competence" which result in limiting their opportunities for better jobs. This is because of the importance of English because it was considered as an essential job requirement in "most professional fields" (Wickramasinghe \& Perera, 2010 in Al-Mahrooqi (2012)).

\subsection{Significance of the Study}

Although many researchers have explored the Willingness to Communicate (WTC) in the Omani context (Al-Amrani, 2011), the research that explored the WTC in a "Public Speaking" course is scarce. The public speaking course is a communicative course, that is provided in the tertiary level, where it is expected that learners interact naturally with the teacher and their peers to produce different spoken out puts including presentations, small group discussions and role-plays (Savaşç1, 2014). Therefore, the current study is an attempt to explore the students perceptions of their own WTC when they are offered a public speaking course in the college. The public speaking course in the current context is designed to prepare the students with conditions to practice various kinds of interactive communication types which include presentations, debates, role plays and group discussions. According to MacIntyre et al. (2001) it is important to "delineate factors that differentially promote WTC inside and outside the classroom". The study also aims at investigating the possible reasons of avoiding to speak in English in a speaking course context. It is hoped that the current study might provide insights to teachers about providing conditions that encourage students to communicate and eliminate the conditions that hinder communication in the class.

\subsection{The Aim and the Questions of the Study}

The study aims at exploring the relationship between the Willingness to Communicate in English in the public speaking classroom and the students' achievement, therefore the study sought to answer the following research questions.

1) How do students perceive their own WTC in the public speaking course?

2) Are there any differences between low achievers and high achievers in students' WTC?

3) Are there any differences between males and females in students' WTC?

4) What are the common reasons for avoiding communications in English?

5) Who supports students to communicate in English? And why?

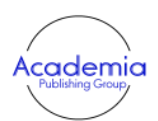

International Journal of Educational Studies

Vol. 2, No.3, pp. 181-189

2019

DOI: $10.53935 / 2641-533 x . v 2 i 3.120$

Funding: This study received no specific

financial support.

Article History:

Received: 12 August 2019

Revised: 16 September 2019

Accepted: 14 October 2019

Published: 12 November 2019

(C) 2019 by the authors; licensee Academic Publishing Group

| 182

\subsection{The Context of the Study}

Oman is considered one of the Middle East countries where English is used as another official language (EFL). Therefore, it might be noticed that Omani students use English for several attributes that includes pursuing their further education, travelling to an English speaking country, business, job opportunities and cultural communications (Al-Issa \& Al-Bulushi, 2012). Due to such importance of English language, Oman has invested huge budget to improve the quality of education in general and English Language in particular. According to a revolutionary project that was initiated in 1998 aiming to enhance the educational system in Oman -particularly introducing the basic education- which leads to a massive reform in different aspects including the reform in the English language teaching field.

According to the new educational system, Omani students in the public schools are required to study English for 12 years, the first ten years from grade1 to 10 using the textbook, English for Me, then in grades 11 and 12 they are introduced to another textbook which is called Engage with English. Both textbooks are 
designed and published by the Curriculums Unit in the Ministry of Education. Teachers are expected to use the communicative approach in teaching, in which their tasks are facilitating the learning process and provide effective learning conditions by the means of pair work and students-centered project work (AlJadani 2012).

In spite of all revolutionary efforts, the graduates of the general educational system are likely to face some problems in learning English, for example the lack of the communicative competence which include the other four sub-competences: grammatical competence, discourse competence, sociolinguistic competence and strategic competence as argued by Al-Issa (2006). According to Al-Mahrooqi (2012) a very limited group of learners were taught using the communicative approach and were rarely engaged in speaking tasks that include group work, presentations, debates, stories and games. They were occasionally provided with some functional language to be used for apologies and polite requests with people around them including their parents.

When these students finish their school education and join the higher education institutes, they show similar weakness and inadequacy in communication skills. As a result these graduates are required to join a foundation program which aims at covering the gap in their linguistic competences which prepares them to join their specializations. Alternatively they are required to get band 5.5 in the IELTS test, for the colleges of technologies in Oman which will enable them to go for a BA degree in their specializations. These requirements might vary in the other governmental and private colleges in the country.

\section{Literature Review}

\subsection{Willingness to Communicate (WTC)}

Research has combined "insights" from two major fields: second language acquisition and communication (Yashima, 2002) in order to discuss the concept of (WTC). It might be noticed that research focuses in many linguistic, psychological, educational and pedagogical conditions that contributes to initiate the (WTC) in the classroom. However the later stage, which is sustaining communication, has not received the same attention of the research. This was the case until the (WTC) in L2 model was framed. According to WTC refers to the "probability of initiation a conversation when given the choice to do so". (WTC) might be exhibited in in written and spoken discourse; however in the current study it is limited to the spoken form in English.

The model of (WTC) has received a considerable attention in relation to other factors that are likely to influence communication. For example stage phobia, anxiety, communication apprehension, shyness, and reticence (McCroskey, 1992). Some of These factors are included in the conceptual frame work that was suggested by and were categorized into six layers. For example, the first layer discusses the actual communication behavior in L2. Then, second layer included intention to communicate, communicative confidence (communication anxiety and perceived communication competence). The third layer included motivational propensities, for example, interpersonal and intergroup motivation in addition to selfconfidence. The fifth layer consists of affective cognitive context (intergroup attitudes, communicative competence and some aspects of social situation). The last layer contains social and individual context.

Research in the (WTC) has been linked to variety of factors in the L2 various contexts. For example, (WTC) can be seen as strong predictor of individual communication anxiety and perceived communicative competence (MacIntyre et al., 2001). Moreover the differences in (WTC) has called for the communicative approach to provide learning conditions -authentic communication when possible- where learners are encouraged to interact in pairs and in groups and this will be discussed in the following section.

\subsection{Communicative Approach}

The Communicative Approach is widely adapted and used by English professionals globally (Richards, 2005). The communicative approach as argued by focuses on developing the four sub competences: strategic, grammatical, discourse and sociolinguistic competence. According to this approach, the pedagogy moves from teacher-centered to student-centered instruction where students are required to engage in variety of tasks with each other, in pairs or groups. The teacher's task is rather a facilitator or learning manager in which he provides the learning conditions including the modification of well-chosen learning materials - authentic when required- that stimulate students to learn language. In such learning contexts, learners are expected to communicate in English inside and maybe outside the class. 
According to Richards (2005) communicative approach should provide the students with language that could be used spontaneously in variety of situations and for different functions. Additionally students are capable of choosing the right language for the right settings including the level of politeness and appropriate spoken and written discourse. Moreover it should enable students to produce different types of texts including narrative, formatives and persuasive presentations. Also to perform well in arguments, interviews and finally knowing how to initiate and keep the flow of discourse regardless their linguistic abilities. It is worthy to mention that the public speaking course in the college is designed to provide such leaning conditions.

\subsection{Unwillingness to Communicate}

Researchers argued that students usually avoid communicating in English inside the classroom due to many pedagogical psychological and cultural reasons. The notion of such resistance to speak in English might be described as "unwillingness to communicate" as suggested. The psychological reasons for such unwillingness might include lack of self-confidence, shyness and fear of losing face, communication apprehension, alienation, and cultural reasons might include the lack of support from others. Moreover reported six factors that hinder the classroom participation: "tiredness, fear of being wrong, insufficient interest in the class, insufficient knowledge in the culture, shyness and insufficient time to formulate ideas".

Furthermore resrarch in the Omani ELT context reported some other reasons for unwilling to communicate. For example. Al-Mahrooqi (2012) reported that the lack of real context or authentic gap that requires communication, is another reason for avoiding to communicate in English. Hence it might be argued that students need to experience using English as a medium to communicate in the "real world" (Zheng \& Huang, 2010).

\subsection{Willingness to Communicate in the ELT Omani Context}

Some cultural aspects make the learning possible whereas other aspects hinder learning. For example, according MacIntyre et al. (2001), affiliation motives that include the interlocutors (friends, teachers, parents). According to Al-Mahrooqi (2012) students enhanced their communication skills though interacting with teachers, peers, group work and English social groups including English and Translation Society. However some precautions must be taken into account when discussing the possible social support to communicate in English. Hence Al-Mahrooqi (2012) stated the importance of "dedicate a course to explicit teaching of communication skills".

According to the research in the Omani ELT context, some possible culture justification for the unwilling to communicate. For example, Al-Amrani (2011) reported that the fear of making mistakes in front of others and losing face especially students of the other gender were the main obstacles that hindered learners from communicating in English. In addition to that, the "control motive" which refers to the speaker desire to lead the discussion and control the space in order to impress the interlocutor is another hindering factor. .

Based on my own experience as a college teacher who taught the public speaking course for two years, it was observed that students in the public speaking course, in this particular context are likely to avoid communicating in English when possible. For example, they use L1 (Arabic) when they seek consultation and guidance during office hours especially for matters regarding giving excuses for being late, being absent or arguing about marks and grades. They assume that they could express themselves better when they use Arabic or maybe because of fear that they might not be able to continue the discussion with the teacher in English due to their limited linguistic skills. Additionally, when they approach the language coordinators to complain about any matter regarding personal learning or teaching issues, they write it in Arabic and if they are asked to resubmit it in English, they are likely to seek teacher's help or prefer not to proceed in the grievance.

\subsection{Theoretical Underpinning}

The psychological theoretical framework underpinning the work of (WTC) is conceptualized by the Theory of Reasoned Action by which suggests that any behavior, including communication is triggered by "an intention to act" based on two factors: the first is personal - an attitude towards a behavior, and the latter is social which include subjective norms. The personal factor includes the positive or negative attitude of taking the [linguistic] risk of initiating the communication and then pairing the consequences. The second 


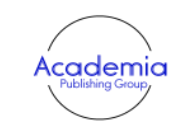

International Journal of Educational

Studies

Vol. 2, No.3, pp. 181-189

2019

DOI: $10.53935 / 2641-533 x . v 2 i 3.120$

Funding: This study received no specific

financial support.

Article History

Received: 12 August 2019

Revised: 16 September2019

Accepted: 14 October 2019

Published: 12 November 2019

(C) 2019 by the authors; licensee Academic

Publishing Group factor is the "subjective norms" which are according MacIntyre et al. (2001), seen as "socially based", "significant others" and "referents" that acting as a supporting learning agent to encourage students to communicate and approve the production of communication.

\subsection{Research Design and Methodology}

The current study is exploratory in nature which aims to explore from the students' perspectives, the State of Art of the (WTC) inside the classroom. To answer the questions of the current study, four classes of public speaking course were selected purposefully which is justified by the time constrains of the current study. According to is a "practical necessity that is "shaped by the time the researcher has available to him, by his framework and by any restrictions placed upon his observations by his host". It is worth mentioning that the total number of the students who registered is 154 student, 102 of them are females. The consent to participate in the study is sough and the students were informed about the study and the confidentiality of the results. Thirty minutes were allocated at the beginning of the selected classes and the researcher went around the classes to provide further clarification and translate some words into Arabic when requested by students.

\subsection{The Instrument}

A questionnaire of (WTC) inside the classroom, that was developed by (reliability 0.78) was modified and administrated in the second semester 2018/2019. Firstly, Students were provided with a five Liker scale and were asked to indicate their choice responding to the 18 statements: 1) Almost never true to me, 2) sometimes true to me, 3) Half of the time true to me, 4) usually true to me, 5) almost always true to me. Earlier to that, one class was selected to administer the questionnaire in order to check the clarity of the language and some item were re-worded which was excluded in the actual implementation of the questionnaire.

In the first part of the questionnaire, some demographic information were required: gender, specialization and the grade group. Students were categorized into three groups according to their midsemester results: low achievers (0-10 marks), average achievers (11-20), high achievers (21-25). This was done based on the tendency of the students in the questionnaire piloting stage to avoid writing their exact mark.

Furthermore, a social support factor which was used in MacIntyre et al. (2001) was added to the questionnaire. To find out students unwillingness to communicate inside the class, ten items were added based on the literature (Wei \& Zhang, 2013), as a new variable which I intended to explore for the current study and it was labeled the reasons for avoiding speaking in English inside the class. It is worth mentioning that the permission to conduct the study was granted by the Head of the English Language Center.

Moreover, it is worth mentioning that I intentionally avoided using the common used (WTC) scale that was designed (McCroskey, 1992) in spite of its high reliability level (0.80). This is because it is found not suitable to the particular context of the study and it seems that it might be more useful for English usage outside the class and for in English as a Second Language contexts.

\section{Results and Discussions}

The data gathered from the questionnaires were analyzed using SPSS version 23. To answer the first question about the students' views of their (WTC), means and standard deviation were calculated then Pearson Correlation was calculated to find the correlation between (WTC) and the students' results in the public speaking courses.

Table 4.1 shows the number of males and females in the study sample. It is noticed that the number of females is higher than males. It is worth mentioning that the total number of all students who registered for the public speaking course in this particular semester 2017\2018 is 154 students, 102 of them are females according to the registration department statics. 
Table-4.1. Number of males and females.

\begin{tabular}{lll}
\hline Gender & Frequency & Percent \\
\hline males & 14 & $28 \%$ \\
females & 36 & $72 \%$ \\
Total & 50 & $100 \%$ \\
\hline
\end{tabular}

Furthermore, Table 4.2 shows the number of students according to their specializations. It might be noticed that the engineering students represents the highest figure. This might be explained by the fact that students of some specializations tend to choose the same timing and sections of the English mandatory courses including the public speaking course, after choosing all the courses in their specializations. As a result, it might be common to find an entire class of students from one specialization or sometimes a mixture of different specializations.

Table-4.2. Number of students.

\begin{tabular}{lll}
\hline & Frequency & Percent \\
\hline Business & 4 & $8 \%$ \\
IT & 20 & $40 \%$ \\
Engineering & 26 & $52 \%$ \\
Total & 50 & $100 \%$ \\
\hline
\end{tabular}

Table 4.3 shows the number of students according to their marks in the progress test which was delivering an informative presentation and using the rubric that was designed by the examination committee in the college. It might be noticed that all students succeed to pass the course, however the average was in the second range between 20-20 marks, which indicates a normal distribution for the marks.

Table 4.3. Number of students according to their marks.

\begin{tabular}{lll}
\hline Mark range & Frequency & Percent \\
\hline $0-10$ & 0 & $0 \%$ \\
$10-20$ & 41 & $82 \%$ \\
$20-25$ & 9 & $18 \%$ \\
Total & 50 & $100 \%$ \\
\hline
\end{tabular}

Then means and standard deviation were calculated to explore the perceived (WTC) from the students' point of view. According to Table 4.4, the results students reported that they communicate in English half of the time (average: 3.35 ) inside the class.

\begin{tabular}{llll} 
& \multicolumn{3}{c}{ Table-4.4. Results. } \\
\hline & N & Mean & Std. Deviation \\
\hline WTC & 50 & 3.35 & .77 \\
\hline
\end{tabular}

Moreover, Table 4.5 shows the order of the reasons that students reported to avoid using English inside the class. It could be observed that the linguistic reasons are on the top of the list whereas the psychological reason "I feel shy" was reported as the least hindering factor for communication.

International Journal of Educational Studies

Vol. 2, No.3, pp. 181-189

2019

DOI: $10.53935 / 2641-533 x . v 2 i 3.120$

Funding: This study received no specific

financial support.

Article History:

Received: 12 August 2019

Revised: 16 September 2019

Accepted: 14 October 2019

Published: 12 November 2019

(C) 2019 by the authors; licensee Academic

Publishing Group

Table-4.5. Order of the reasons.

\begin{tabular}{llll}
\hline Item & No & mean & Std. Deviation \\
\hline I prefer to use Arabic language to explain important study matters. & 50 & 3.42 & 1.42 \\
It is difficult for me to choose the proper word in English. & 50 & 3.14 & 1.04 \\
I feel communicating in English is cognitively a demanding task & 50 & 3.06 & 1.30 \\
Teachers always correct me when I speak. & 50 & 3.04 & 1.39 \\
I feel afraid of making mistakes in front of others and losing face & 50 & 2.86 & 1.35 \\
Teachers do not provide me with opportunities for speaking & 50 & 2.80 & 1.26 \\
I think the topics are boring & 50 & 2.78 & 1.29 \\
I think there is no real need to communicate in English. & 50 & 2.76 & 1.22 \\
I feel shy to speak English in front of other students & 50 & 2.62 & 1.93 \\
\hline
\end{tabular}


Table 4.6 shows the answer to the question: who sports you to speak English inside the class. It can be seen that teachers were the most frequent social supporter who encourages students to speak in English inside the class whereas the class mates, academic advisor and college management were reported as the least supportive agents for encouraging students to speak English in the class. This is maybe could be justified by the fact that most of administrative staff in the college but not in the English language Center are Non English speakers and rarely speak English. According to MacIntyre et al. (2001), friends were the highest group who provides social support to use English inside and outside the classroom, however this is maybe due to the fact that the sample of their study were French immersion students who lived in a unilingual Anglophone community and they are motivated to establish friendship bonds with the target community. It is might be claimed as Clement, 1986 (in MacIntyre, Baker, Clément, and Donovan (2003), p374)) that "language acquisition is eminently bond to a social context".

\begin{tabular}{lll}
\multicolumn{3}{c}{ Table-4.6. Answer to the questions. } \\
\hline & Frequency & Percent \\
\hline My teacher & 23 & 46 \\
My brothers and sisters & 12 & 24 \\
My friends & 7 & 14 \\
My parents & 5 & 10 \\
My classmates & 1 & 2 \\
My academic advisor & 1 & 2 \\
College management & 1 & 2 \\
Total & 50 & $100 \%$ \\
\hline
\end{tabular}

When the students were requested to justify their choice of teachers as the most supportive agent for speaking English inside the classroom, they reported that because of the teacher firmness to use L2 because they themselves do not speak Arabic, so the only way for communication in the class is English. Also, they argued that, the only one who I can trust to correct my mistakes in English is the teacher.

To answer the second question about differences between males and females in relation to the (WTC), independent samples test. Table 4.7 which shows that there were no significant differences between males and females in relation to (WTC). These result matches with study of Valadi, Rezaee, and Baharvand (2015) which shows no differences between males and females in relation to (WTC). Al-Mahrooqui, Tuzlukova, and Denman (2016) study found that girls outperform boys in the communication skills which was justified by social and cultural factors, as girls are likely to exert more efforts in their studies. This is maybe because the student in the current study spend many years in the college and took many courses throughout their study life in the college (most of them in the fourth year), which make them feel comfortable to communicate in the class and eliminate possible shyness.

\begin{tabular}{llllll}
\multicolumn{7}{c}{ Table-4.7. Analysis. } \\
\hline & Mean & Std. deviation & t & Df & sig \\
\hline Males & 3.6 & 0.58 & 1.28 & 48 & 0.20 \\
Females & 3.2 & 0.83 & & & \\
\hline
\end{tabular}

Finally in order to find the differences between average achievers (10-20) and high achievers (20-25) in their willingness to communicate, ANOVA test was conducted. The results showed that there no significant significance between the two groups.

Table-4.8. Group analysis.

\begin{tabular}{llllll}
\hline & Sum of squares & Df & Mean squre & F & Sig \\
\hline Between groups & 2.9 & 2 & 1.45 & 2.55 & 0.89 \\
Within groups & 26.8 & 47 & 0.57 & & \\
Total & 29.7 & 49 & & & \\
\hline
\end{tabular}




\section{Recommendations and Implications}

The starting point of the current study was to explore the student's perceptions about their (WTC) in English in a public speaking course. The result revealed that they communicate half of the time inside the class and that is because of their limited linguistic competences. Therefore policy makers, curriculum designers and teachers should consider addressing the common linguistic problems might face the Omani students when they are willing to communicate in English and training students to overcome this challenge.

\section{Limitations of the Study}

Throughout the study some challenges were identified and need to be addressed if the study is to be replicated in a different context. For example, the sample of the study was limited, so maybe conducting the same study using a sample of the study from all seven colleges of technology in the country.

Additionally, biases resulted from self-report questioners as they might be affected by social desirability, therefore researchers might use interviews in addition to the questionnaires. Another solution by MacIntyre et al. (2003) who recommended "observing learners in [real ] learning situations rather than simply asking them what would they do in those situations". Hence, using observations in the class or analyzing the videos of the presentations and small group discussions -because they are already recorded or using document analysis for the feedback forms of the students- might be another rich source of data for a similar study.

Finally since the study was limited to the spoken communication, it might be recommended to investigate the written communication courses including Technical writing 1, Technical writing 2 and The technical communication courses.

\section{References}

Al-Amrani, S. N. (2011). Willingness to communicate by Arab EFL learners: Conceptualization and realisation. Paper presented at the ALAA- ALANZ Conference, University of Canberra \& Australian National University, Canberra, 29 November - 3 December 2011.

Al-Issa, A. (2006). Language problems facing Omani learners of English. ORTESOL Journal, 24, 19-26.

Al-Issa, A. S., \& Al-Bulushi, A. H. (2012). English language teaching reform in Sultanate of Oman: The case of theory and practice disparity. Educational Research for Policy and Practice, 11(2), 141-176.

Al-Jardani, K. (2012). English language curriculum in Oman. International Journal of English Linguistic, 2(5), 40-44.

Al-Mahrooqi, R. (2012). English communication skills: How are they taught at schools and Universities in Oman. English Language Teaching, 5(4), 124-130.

Al-Mahrooqui, R., Tuzlukova, V., \& Denman, C. (2016). Tertiary education and communication skills development of omani learners: Students perspective. The International Journal of Communication and Linguistic Studies, 14(2), 15-34.

Borg, S. (2006). Classroom research in English Language teaching in Oman. Sultanate of Omsan, Oman: Ministry of Education.

MacIntyre, P., Baker, S., Clément, R., \& Donovan, L. (2003). Talking in order to learn: Willingness to communicate and intensive language programs. Canadian Modern Language Review, 59(4), 589-608.

MacIntyre, P. D., Baker, S. C., Clément, R., \& Conrod, S. (2001). Willingness to communicate, social support, and language-learning orientations of immersion students. Studies in Second Language Acquisition, 23(3), 369-388.

McCroskey, J. C. (1992). Reliability and validity of the willingness to communicate scale. Communication Quarterly, 40(1), 16-25.

Moody, J. (2009). A neglected aspect of ELT in the Arabian Gulf: Who is communication between, In English's and Literatures-inEnglish in a Globalized World. Paper presented at the Proceedings of the 13th International Conference on English in Southeast Asia.

Peng, J. E., \& Woodrow, L. (2010). Willingness to communicate in English: A model in the Chinese EFL classroom context. Language Learning, 60(4), 834-876.

Richards, J. C. (2005). Communicative language teaching today. Singapore: SEAMEO Regional Language Centre.

Savaşç1, M. (2014). Why are some students reluctant to use L2 in EFL speaking classes? An action research at tertiary level. ProcediaSocial and Behavioral Sciences, 116, 2682-2686. Available at: https://doi.org/10.1016/j.sbspro.2014.01.635.

Valadi, A., Rezaee, A., \& Baharvand, P. K. (2015). The relationship between language learners' willingness to communicate and their oral language proficiency with regard to gender differences. International Journal of Applied Linguistics and English Literature, 4(5), 147-153.

International Journal of Educational

Studies

Vol. 2, No.3, pp. 181-189

2019

DOI: $10.53935 / 2641-533 x . v 2 i 3.120$

Funding: This study received no specific

financial support.

Article History:

Received: 12 August 2019

Revised: 16 September 2019

Accepted: 14 October 2019

Published: 12 November 2019

(C) 2019 by the authors; licensee Academic

Publishing Group

| 188

Wei, Y., \& Zhang, L. (2013). The survey on barriers of Oral English learning for College Students in China. English Language Teaching, 6(6), 68-76.

Yashima, T. (2002). Willingness to communicate in Second Language: The Japaneses EFL context. The Modern Language Journal, $86(1), 54-66$.

Zheng, L., \& Huang, J. (2010). A study of Chinese EFL learners' Pragmatic failure and the implicatios for College English teaching. Plyglossia, 18, 41-45. 


\section{Index (A)}

A Questionnaire on Students' Willingness to Communicate in English inside the Classroom

Dear students:

The following statements describe tasks or situations inside a speaking class and outside the classroom, kindly choose the box which best describes your practices.

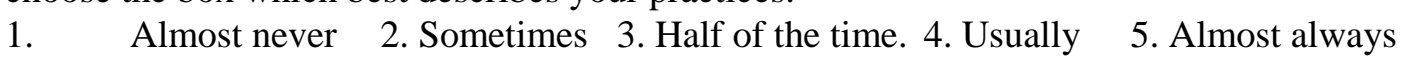

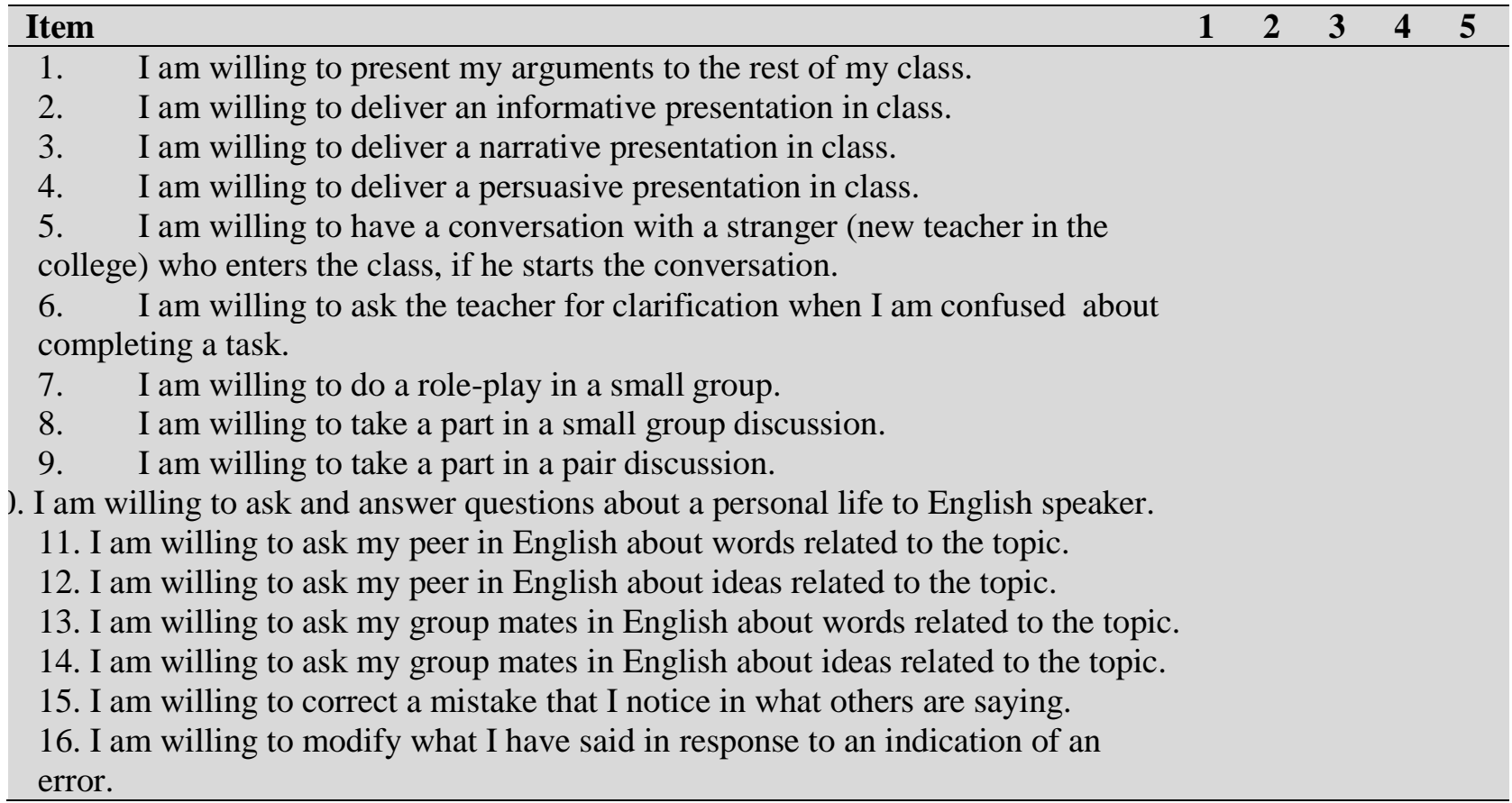

Social support :

Who usually encourages you MOST to speak in English (choose one option).

- My teacher.

- My parents.

- My brothers and/or sisters.

- My friends.

- My classmates.

- My academic advisor.

- College management.

- Others, please specify:

- Why do you think this agent encourages you to speak in English?

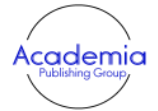

International Journal of Educational Studies

Vol. 2, No.3, pp. 181-189

2019

DOI: $10.53935 / 2641-533 x . v 2 i 3.120$

Funding: This study received no specific

financial support.

Article History:

Received: 12 August 2019

Revised: 16 September 2019

Accepted: 14 October 2019

Published: 12 November 2019

(0) 2019 by the authors; licensee Academic Publishing Group

\begin{tabular}{llllll}
\hline Why do you avoid speaking in English in class? & 1 & 2 & 3 & 4 & 5 \\
\hline o It is difficult for me to choose the proper word in English. & & & & \\
o I prefer to use Arabic Language to explain important study & & & & \\
matters. & & & & \\
o Teachers do not provide me with opportunities for speaking. & & & \\
o Teachers always correct me when I speak. & & & \\
\hline
\end{tabular}

